\title{
EFFECTS OF DIETARY SUPPLEMENTATION WITH DIFFERENT POLYUNSATURATED FATTY ACIDS ON EXPRESSION OF GENES RELATED TO SOMATOTROPIC AXIS FUNCTION IN THE LIVER, SELECTED BLOOD INDICATORS, MILK YIELD AND MILK FATTY ACIDS PROFILE IN DAIRY COWS
}

\author{
Essa Dirandeh ${ }^{1,2}$, Armin Towhidi² ${ }^{2 *}$,Zarbakht Ansari ${ }^{1}$, Saeeid Zeinoaldini², Mehdi Ganjkhanlou ${ }^{2}$ \\ ${ }^{1}$ Department of Animal Science, Sari Agricultural Sciences and Natural Resources University, Sari, \\ Iran \\ ${ }^{2}$ Department of Animal Science, University of Tehran, Alborz, Iran \\ •Corresponding author: atowhidi@ut.ac.ir
}

\begin{abstract}
The objective of this study was to investigate whether dietary supplementation with different polyunsaturated fatty acids (PUFAs) affects expression of genes related to somatotropic axis and the plasma concentrations of insulin, glucose, non-esterified fatty acids (NEFA), beta hydroxyl butyrate acids (BHBA) and insulin-like growth factor 1 (IGF1) and milk fatty acids profile. Right after calving, Holstein cows $(n=45)$ were randomly assigned to one of three diets supplemented with roasted whole soybean as a source of omega- 6 PUFA (omega-6, $n=15)$, linseed as a source of omega-3 PUFA (omega-3, $n=15$ ) or palm oil (control, $n=15$ ). Each cow was in the study over a period of 70 days. Blood samples were collected every two weeks from day 1 to 70 of lactation and plasma concentrations of insulin, glucose, NEFA, BHBA and IGF1 were determined. Liver samples were taken from a subset of 18 cows (6 per diet) at day 70 postpartum and hepatic mRNA level of total growth hormone-receptor 1A (GHR1A), insulin receptor (INSR), IGF1 and insulinlike growth factor binding protein (IGFBP2) was assessed. Experimental diets did not affect milk yield. Plasma glucose and insulin concentrations were greater for omega-3 treatment compared to omega- 6 and control treatments. Cows fed diets enriched in omega-3 exhibited greater INSR and GHR1A mRNA expression, and a tendency for greater IGF1 mRNA expression in the liver compared to omega-6 and control cows. Plasma IGF1 concentration was significantly higher in omega- 3 treatment compared with omega- 6 and control treatments. Results of this study suggest that feeding omega-3 PUFAs during early postpartum couples with the somatotropic axis, leading to an increase in plasma IGF1 concentration in dairy cows.
\end{abstract}

Key words: dairy cows, PUFA, GHR1A, INSR, IGF1, IGFBP2 mRNA 
The periparturient period in dairy cows is associated with insulin resistance, which increases the availability of glucose, amino acids and fatty acids (FA) to mammary gland (Bell and Bauman, 1997; Renaville et al., 2002). Conceptually, exaggerated insulin resistance may enhance the degree of FA mobilization from adipose tissue, and further increase plasma NEFA concentration and decrease IGF1, which is associated with poor reproductive performance (Pires et al., 2007).

Growth hormone $(\mathrm{GH})$ directly acts on liver and adipose tissue (e.g. increases gluconeogenesis and decreases lipogenesis) as well as indirectly through insulin-like growth factor 1 (IGF1) and insulin-like growth factor binding proteins (IGFBP) on muscle and mammary gland (e.g. increases utilization of NEFA and increases mammary blood flow; Renaville et al., 2002). However, it has been shown that in some metabolic situations during early lactation period, elevated plasma growth hormone $(\mathrm{GH})$ concentrations fail to stimulate an increase in hepatic IGF1 synthesis (Fenwick et al., 2008; Lucy, 2008). In cattle, both insulin and IGF1 interact synergistically with gonadotrophin hormones to promote follicular growth, steroidogenesis, and enhance maximum size of the pre-ovulatory follicle (Wathes et al., 2003). Perturbations in metabolic status, indicated by changes in circulating concentrations of IGF1, have been reported to be associated with reproductive efficiency (Wathes et al., 2003; Patton et al., 2007).

In addition to $\mathrm{GH}$, it has been suggested that insulin is an important endocrine factor regulating somatotropic axis (Butler et al., 2003). In this regard, insulin treatment has been shown to restore liver GH receptor expression and IGF1 release in dairy cows (Butler et al., 2003). Moreover, concomitant insulin and glucose intravenous infusion compared with infusing separately with either saline or glucose caused an increase in plasma IGF1 concentrations in cows (Léonard and Block, 1997). Other studies have demonstrated that GH binding to hepatic microsomal membranes is enhanced in insulin-treated cows, and that GH binding is correlated with plasma insulin concentrations (Leonard et al., 2001).

Dietary FA profile can modulate the response to insulin in non-ruminants; particularly, omega-3 PUFA, such as C18:3n-3, C20:5n-3 and C22:6n-3, may prevent the development of insulin resistance in humans and rodents (Clarke, 2000; Delarue et al., 2004). In agreement with these findings, abomasal infusion of fish oil (4\% of DMI) to beef steers increased key intermediaries of intracellular insulin signaling cascade in muscle, enhanced whole body insulin-induced disposal of amino acids and glucose, compared to the infusion of a control fat source composed of $60 \%$ cotton oil and 40\% olive oil (Gingras et al., 2007). As a result, dietary PUFA supplementation in dairy cows, particularly omega-3 fatty acids, may decrease the probability of insulin resistance, and finally affect somatotropic axis action.

The aim of this study was to determine the effect of different dietary PUFAs supplementation on mRNA expression of genes related to the somatotropic axis function in the liver of dairy cows. In addition, plasma concentrations of insulin, glucose, NEFA, BHBA and IGF1 as well as milk yield and milk fatty acid profiles were investigated. 


\section{Material and methods}

\section{Cows and treatments}

This experiment was performed according to the procedures laid down by the Iranian Ministry of Agriculture (experimental permission no. 858).

Table 1. Ingredient and chemical composition of diets based on the palm oil (Control, $n=15$ ), linseed as a source of omega-3 PUFA (Omega-3, $n=15$ ) or roasted whole soybean as a source of omega-6 PUFA (Omega-6, $\mathrm{n}=15$ )

\begin{tabular}{|c|c|c|c|}
\hline & \multicolumn{3}{|c|}{ Treatments } \\
\hline & control & Omega-3 & Omega-6 \\
\hline \multicolumn{4}{|l|}{ Ingredient ( $\%$ of dry matter) } \\
\hline Alfalfa hay (mid bloom) & 26.72 & 26.72 & 26.72 \\
\hline Corn silage & 22.1 & 22.1 & 22.1 \\
\hline Dehydrated beet pulp & 2.97 & 2.97 & 2.97 \\
\hline Ground corn grain & 9.74 & 9.74 & 9.74 \\
\hline Rolled barley grain & 9.65 & 9.65 & 9.65 \\
\hline Molasses & 0.78 & 0.76 & 0.78 \\
\hline Wheat bran & 0.32 & 0.20 & 0.71 \\
\hline Soybean meal ( $48 \%$ crude protein) & 8.81 & 7.93 & 3.03 \\
\hline Roasted whole soybean & 0 & 0 & 7.31 \\
\hline Corn gluten meal ( $60 \%$ crude protein) & 1.83 & 1.83 & 1.83 \\
\hline Cottonseed meal & 3.39 & 3.08 & 3.14 \\
\hline Whole cottonseed & 1.51 & 1.48 & 1.51 \\
\hline Extruded linseed & 0 & 4.06 & 0 \\
\hline Canola meal (solvent) & 4.6 & 3.26 & 4.4 \\
\hline Wheat rolled & 2.64 & 2.69 & 2.69 \\
\hline Palm oil & 1.41 & 0 & 0 \\
\hline Limestone & 0.45 & 0.45 & 0.45 \\
\hline Vitamin and mineral premix ${ }^{1}$ & 0.89 & 0.89 & 0.89 \\
\hline Dicalcium phosphate & 0.54 & 0.54 & 0.54 \\
\hline Magnesium oxide & 0.20 & 0.20 & 0.20 \\
\hline Salt & 0.45 & 0.45 & 0.45 \\
\hline Sodium bicarbonate & 1.00 & 1.00 & 1.00 \\
\hline \multicolumn{4}{|l|}{ Chemical composition } \\
\hline Net energy for lactation (Mcal/kg of dry matter) & 1.58 & 1.58 & 1.58 \\
\hline Fat (\% of dry matter) & 4.00 & 4.00 & 4.00 \\
\hline Crude protein (\% of dry matter) & 17.90 & 17.85 & 17.85 \\
\hline Neutral detergent fiber ( $\%$ of dry matter) & 34.40 & 33.90 & 34.10 \\
\hline Acid detergent fiber ( $\%$ of dry matter) & 20.40 & 20.50 & 20.40 \\
\hline
\end{tabular}

${ }^{1}$ Contained (per kilogram): 16,000,000 IU of vitamin A; 3,200,000 IU of vitamin D; 48,000 IU of vitamin E; $24.0 \mathrm{~g}$ of $\mathrm{Mn} ; 24.0 \mathrm{~g}$ of $\mathrm{Zn} ; 24.0 \mathrm{~g}$ of Fe; $12.8 \mathrm{~g}$ of Cu; $1.44 \mathrm{~g}$ of I; $0.32 \mathrm{~g}$ of Se; and $0.32 \mathrm{~g}$ of Co. 
Forty-five multiparous Holstein cows $($ milk $=35 \pm 2.1 \mathrm{~kg} / \mathrm{d})$ from a commercial dairy herd were blocked by predicted calving date and parity and randomly allocated to one of three experimental diets supplemented with: 1) palm oil (control; $n=15$ ); 2) rolled linseed (omega-3; $n=15$ ) or; 3 ) whole roasted soybean (omega-6; $n=15$ ). The diets were formulated to meet or exceed nutrient requirements for lactating cows (NRC, 2001) and to be isonitrogenous and isoenergetic (Table 1). Fatty acid analyses were made for whole roasted soybean, linseed and palm oil before starting the study. The total mixed ration (TMR) was also sampled and analyzed for chemical composition (for details see below). Supplementation of FA was at $1.5 \%$ of dietary dry matter.

Diets were fed twice daily (08:00 and 16:00 h) for ad libitum intake (10\% of refusals on as fed basis) from calving until 70 days postpartum (dpp). Total mixed rations were sampled every $2 \mathrm{wk}$ and pooled each month. Feed samples were dried at $65^{\circ} \mathrm{C}$ for $24 \mathrm{~h}$ and then ground to pass through a 1-mm screen (Retsch SM 100, Retsch GmbH, Haan, Germany). Cows were milked three times per day at 07:00, 14:00, and 24:00 h and yields were recorded automatically (BouMatic, MadisonWisconsin, USA).

\section{Body condition score}

Cows were evaluated for BCS at calving, 20, 40 and 70 days post-partum (dpp). Scores were given by one experienced veterinarian based on a 1 (thin) to 5 (obese) predetermined scales using a quarter point system (Edmonson et al., 1989). Changes in BCS were obtained by subtracting BCS at $20 \mathrm{dpp}$ from BCS at parturition, BCS at $40 \mathrm{dpp}$ from BCS at $20 \mathrm{dpp}$, and BCS at $70 \mathrm{dpp}$ from BCS at $40 \mathrm{dpp}$.

\section{Milk fatty acid profiles}

Milk was sampled from 3 consecutive milkings on each day. Fatty acid extraction was done according to the Folch method (Folch et al., 1957) with some modifications. Briefly, chloroform/methanol $(2: 1, \mathrm{v} / \mathrm{v})$ containing $0.005 \%$ butylated hydroxytoluene (as antioxidant) was added (usually $5 \mathrm{~mL}$ solvent added to $50-100 \mu \mathrm{l}$ sample) and vortexed for $1 \mathrm{~min}$ and then left at $4^{\circ} \mathrm{C}$ overnight. One $\mathrm{mL}$ of $0.9 \% \mathrm{NaCl}$ was added and mixed again. The chloroform phase (e.g. lower phase) was transferred to a clean tube and care was taken not to transfer any remaining aqueous phase along with the chloroform phase. Remaining FA in original tubes was extracted twice with $2.0 \mathrm{~mL}$ of chloroform and these two extractions were then combined to the first one. Fatty acid methyl esters were prepared according to methods described previously (Morrison and Smith, 1964; Salem et al., 1996) and using the BF3/methanol reagent ( $1 \mathrm{~mL}$ of $14 \% \mathrm{BF} 3 / \mathrm{MeOH}$ reagent).

\section{Blood collection and insulin, glucose, NEFA, BHBA and IGF1 analyses}

Blood samples were collected from all animals every two weeks from $\mathrm{d} 1$ to 70 of dpp via venipuncture from the coccygeal vein before the morning meal. Blood was collected in vacutainers (BD, Franklin Lakes, NJ) containing EDTA and samples were centrifuged at $1,500 \times \mathrm{g}, 20$ min within $2 \mathrm{~h}$ after collection. Plasma was harvested and stored at $-20^{\circ} \mathrm{C}$ until further processing. Plasma concentrations of glu- 
cose (Glucotrend, Roche, England), NEFAs (Cat. No. FA 115, Randox Laboratories Ltd, UK) and BHBA (Abbott Diabetes Care Ltd. Rang Road. Witney, Oxin, OX29 OYL., UK) were determined enzymatically using a spectrophotometer (Shimadzu 2100 , Kyoto, Japan). Intra- and inter-assay coefficients of variation were $<5 \%$. Plasma insulin was measured using a commercially available bovine ELISA kit supplied by Mercodia AB (Mercodia, Uppsala, Sweden). Analytical range was 0.05-3.0 $\mu \mathrm{g} / \mathrm{L}$, with a sensitivity of $0.025 \mu \mathrm{g} / \mathrm{L}$ and intra-assay coefficient of variation was $<4 \%$. Concentrations of total IGF1 were measured using the DSL-10-2800 ACTIVE non-extraction IGF1 ELISA kit (Diagnostic Systems Laboratories, Webster, Texas, USA).

\section{Liver biopsy}

Liver tissues (approximately $100 \mathrm{mg}$ ) were taken from a subset of 16 cows (six per treatment) on $70 \mathrm{dpp}$ by percutaneous punch biopsy as described by Rhoads et al. (2008). Briefly, a biopsy site between the 11 th and 12 th ribs on the right side was shaved, and disinfected with an iodine scrub solution and $70 \%$ ethanol. Local anesthesia ( $5 \mathrm{~mL}$ of $2 \%$ lidocaine hydrochloride solution) was administered to desensitize the incision site. An incision of approximately $1 \mathrm{~cm}$ was made through the skin and the biopsy instrument (Western Alloys and Metals, Vancouver, B.C) was used to pierce the intercostal muscles and peritoneum. Approximately $100 \mathrm{mg}$ of liver tissue was collected, rinsed with sterile PBS, placed in a screw-cap microcentrifuge tube, snap-frozen in liquid nitrogen, and stored at $-80^{\circ} \mathrm{C}$ until RNA extraction.

\section{RNA extraction and cDNA synthesis}

Total RNA was extracted from liver samples using the RNXTM (-Plus) solution (RN7713C, Qiagen Inc., Germany) according to the manufacturer's instructions. Integrity of RNA was verified by agarose gel (1\%) electrophoresis. The RNA concentration and assessment of purity (e.g., protein contamination) were determined using UV absorbance (260-280 nm). Total RNA (1 $\mu \mathrm{g})$ was first treated with $1 \mathrm{U}$ DNase (Invitrogen) to remove any contaminating DNA. The RNA was reverse transcribed in the presence of $1 \mathrm{mM}$ oligo(dT) primer and $4 \mathrm{U}$ Omniscript RTase (Qiagen) according to the manufacturer's instructions.

\section{Measurement of mRNA expression using Real-time PCR}

Quantitative real-time PCR (qRTPCR) analyses were used for measurement of relative mRNA abundance. PCR amplification, detection and data analyses were performed with a real-time PCR System (Rotor gene 3000, Corbett, Australlia). PCR amplifications included an initial step of $10 \mathrm{~min}$ at $95^{\circ} \mathrm{C}$, followed by 40 cycles of a two-phase PCR (denaturation at $95^{\circ} \mathrm{C}$ for $20 \mathrm{~s}$; annealing and extension at $60^{\circ} \mathrm{C}$ for $30 \mathrm{~s})$. Reaction mixtures $(15 \mu \mathrm{L})$ included $1.5 \mu \mathrm{L}$ cDNA as template, $7.5 \mu \mathrm{L}$ SYBRGreen PCR Master Mix (Applied Biosystems, Carlsbad, CA, USA), $1 \mu \mathrm{L}$ of forward, $1 \mu \mathrm{L}$ of reverse primers and $4 \mu \mathrm{L}$ of double distilled water. The standard curves were composed of serial dilutions of cDNA. Samples were run in duplicate, and were expressed relative to 18sRNA as housekeeping gene, which was stable under the culture conditions used. Oligonucleotide primer sequences and GenBank Accession numbers for all gene transcripts are listed in Table 2. 
Table 2. Oligonucleotide primer sequences for all gene transcripts

\begin{tabular}{l|c|l|l}
\hline \multicolumn{1}{c}{ Gene } & Primer & \multicolumn{1}{c}{ Sequence (5'to 3') } & $\begin{array}{c}\text { Gene accession number } \\
\text { or reference }\end{array}$ \\
\hline GHR1A & F & CCAGCCTCTGTTTCAGGAGTGT & Rhoads et al., 2008 \\
INSR & R & TGCCACTGCCAAGGTCAAC & \\
& F & TCC TCA AGG AGC TGG AGG AGT & Pfafflet al., 2002 \\
IGF1 & R & GCT GCT GTC ACA TTC CCC A & \\
& F & TTGGTGGATGCTCTCCAGTTC & X15726 \\
IGFBP2 & R & GCACTCATCCACGATTCCTGT & \\
& F & GCATGGCCTGTACAACCTCAA & AF074854 \\
18 S rRNA & R & TCCCGGTGTTAGGGTTCACA & \\
& F & GTAACCCGTTGAACCCCATT & DQ222453 \\
& R & CCATCCAATCGGTAGTAGCG & \\
\hline
\end{tabular}

The relative mRNA abundance of each gene was calculated using the $2^{-\Delta \Delta C t}$ method as described in the User Bulletin \#2 (Applied Biosystems 1997; ABI PRISM 7700 Sequence Detection System). The $\Delta \mathrm{Ct}$ value was calculated by subtracting the average (from triplicate) $\mathrm{Ct}$ value of the 18sRNA transcript from the average $\mathrm{Ct}$ value of selected genes. Then, the $\Delta \Delta \mathrm{Ct}$ was calculated by subtracting the $\Delta \mathrm{Ct}$ value of the control group from the $\Delta \mathrm{Ct}$ value of each treatment (average $\Delta \mathrm{Ct}$ value of all animals within a treatment). Then, the $2^{-\Delta \Delta \mathrm{Ct}}$ was calculated.

\section{Statistical analyses}

Plasma concentrations of IGF1, insulin and blood metabolites (i.e., BHBA, NEFA and glucose) were analyzed using repeated measures responses of the mixed model procedure of SAS (SAS Institute, 2000), with the following model:

where:

$$
Y_{i k j}=\mu+\alpha_{i}+\beta_{j}+(\alpha \beta)_{i j}+e_{i j k}
$$

$\mu$ is the population mean,

$\alpha_{i}$ is a population parameter corresponding to treatment (diet) $i$,

$\beta_{j}$ is the fixed effect of sampling day or time $j$,

$(\alpha \beta)_{i j}$ is interaction effects of treatment and sampling day or time,

$e_{i j k}$ is the residual error.

Data were tested for normal distribution of the residuals by the PROC UNIVARIATE procedure of SAS.

Gene expression data, calculated using $2^{-\Delta \Delta \mathrm{Ct}}$ method, were expressed as fold change over the control group, which was given a value of 1 (Dirandeh et al., 2015). Gene expression data was checked for adherence to a normal distribution (PROC UNIVARIATE, SAS v 9.1, 2000) and were analyzed using the SAS (version 9.1, SAS Institute, Cary, NC, USA). Differences between means were tested using Tukey test and were considered significant at $\mathrm{P}<0.05$ whereas $\mathrm{P}<0.10$ was interpreted as a tendency. 


\section{Results}

\section{Dry matter intake, milk production and body condition score}

There was no difference between groups (mean \pm S.E.M.) in parity $(3.0 \pm 1.90)$ or body condition score $(\mathrm{BCS})$ at calving $(3.2 \pm 0.07)$. The omega- 6 to omega-3 FA ratio was $4.2,3.2$, and 1.2 for omega- 6 , control, and omega-3 treatments, respectively (Table 1). The greater omega-6: omega-3 ratio of the roasted whole soybean diet (omega-6) was due to the greater quantity of linoleic acid (C18:2, 58.7\%), whereas the low omega-6:omega-3 ratio in the linseed diet (omega-3) was because of the greater amount of linolenic acid in linseed (C18:3, 29.70\%). The FA composition of the TMR was characterized by greater proportions of linoleic acid and $\alpha$-linolenic acid in diets supplemented with roasted whole soybean and linseed, respectively.

Table 3. Fatty acid (FA) profile (g/100 g of FA) of milk samples, milk production, DMI and BCS in the Holstein dairy cows fed diets supplemented with palm oil (Control, $n=15)$, linseed as a source of omega-3 PUFA (Omega-3, n=15) or roasted whole soybean as a source of omega-6 PUFA (Omega-6, $\mathrm{n}=15)$

\begin{tabular}{l|c|c|c}
\hline \multirow{2}{*}{ Fatty acid } & \multicolumn{3}{|c}{ Treatments } \\
\cline { 2 - 4 } & control & Omega-3 & Omega-6 \\
\hline C $<12$ & 0.38 & 0.36 & 0.37 \\
C14:0 & 0.47 & 3.03 & 0.50 \\
C16:0 & $33.21 \mathrm{a}$ & $12.36 \mathrm{~b}$ & $14.31 \mathrm{~b}$ \\
C16:1 & 1.01 & 0.93 & 1.05 \\
C18:0 & $16.08 \mathrm{a}$ & $2.75 \mathrm{~b}$ & $3.02 \mathrm{~b}$ \\
C18:1 & 12.18 & 18.47 & 20.58 \\
C18:2 & $26.78 \mathrm{a}$ & $30.93 \mathrm{a}$ & $47.42 \mathrm{~b}$ \\
C18:3 & $8.33 \mathrm{a}$ & $29.73 \mathrm{~b}$ & $11.25 \mathrm{a}$ \\
C20:0/1 & 1.52 & 1.45 & 1.50 \\
SCFA & \\
MCFA & \\
LCFA & 0.382 & 0.365 & 0.377 \\
Omega-3 & $34.68 \mathrm{a}$ & $16.27 \mathrm{~b}$ & $15.85 \mathrm{~b}$ \\
Omega-6 & $64.89 \mathrm{a}$ & $83.33 \mathrm{~b}$ & $83.77 \mathrm{~b}$ \\
Omega-6 to omega-3 FA ratio & $8.33 \mathrm{a}$ & $29.73 \mathrm{~b}$ & $11.25 \mathrm{a}$ \\
Milk yield (kg d $^{-1}$ ) & $26.78 \mathrm{a}$ & $30.93 \mathrm{a}$ & $47.42 \mathrm{~b}$ \\
DMI (kg d $^{-1}$ ) & $3.20 \mathrm{a}$ & $1.00 \mathrm{~b}$ & $4.20 \mathrm{c}$ \\
Milk fat (\%) & 45.57 & 46.05 & 45.50 \\
BCS $^{3}$ & 23.3 & 24.1 & 23.6 \\
\hline
\end{tabular}

$\mathrm{a}, \mathrm{b}-$ means within a row with different superscripts differ $(\mathrm{P}<0.05)$.

'SCFA, Short-chain fatty acids: C4:0 to C12:0.

${ }^{2}$ MCFA, Medium-chain fatty acids: C12:0 to C17:0.

${ }^{3}$ LCFA, Long-chain fatty acids: $>$ C18:0. 
There was no effect of treatment on dry matter intake and body condition score $(\mathrm{P}>0.05$, Table 3$)$. The DMI increased with time but no treatment $\times$ day interaction was detected $(\mathrm{P}=0.98)$. Similarly, milk yield increased over time $(\mathrm{P}<0.001)$ but was not affected by diet $(\mathrm{P}=0.45)$. Milk composition was similar among diets, except milk fat percentage and yield of milk fat, which were less in the omega-3 treatment than in the other two treatments $(\mathrm{P}=0.01$, Table 3$)$.

\section{Effects of dietary treatments on milk fatty acid profile}

The FA composition of milk was affected by diets (Table 3 ). There was no difference in short chain fatty acid concentrations in the milk among the dietary treatments. Lower concentrations of medium chain fatty acid were observed in cows fed with the omega-3 or omega-6 FA supplements compared with the control cows (Table 3). The proportion of C16:0 and C18:0 was lower in the milk from cows fed with omega-3 and omega-6 FA supplements compared with cows fed control treatment. Linoleic acid (C18:2) content in milk was higher for cows fed omega-6 fatty acids compared to those fed omega-3. There was no difference between treatments for saturated fatty acids (SFA) content in milk but PUFA content was higher in cows fed omega- 3 or omega- 6 fatty acids compared to that in control cows. The concentration of long chain fatty acids in milk was higher in cows fed omega-3 or omega- 6 FA supplements than in cows fed control. The concentration of C18:3 FA was the highest in cows fed a diet supplemented with omega-3 FA than in those fed either a diet supplemented with omega- 6 or control.

\section{Effects of dietary treatments on plasma insulin, glucose, NEFA, BHBA and IGF1}

Plasma glucose concentration increased with time $(\mathrm{P}<0.001$, Figure 1) and was greater in the omega-3 group, compared with control and omega-6 group (Table 4). Plasma insulin increased with days in milk (DIM, P<0.001, Figure 1) and was significantly increased in cows fed the omega-3 diet compared with that in cows in the other dietary groups (Table 4). Plasma IGF1 concentration was higher for omega- 6 cows compared to omega- 6 or control cows $(\mathrm{P}=0.03)$.

Mean plasma concentrations of NEFA and BHBA are shown in Table 4. Concentration of NEFA was affected $(\mathrm{P}=0.01)$ by diets and decreased $(\mathrm{P}<0.001)$ with increasing DMI (Figure 1). There was no difference among diets for BHBA concentrations.

\section{Relative mRNA abundance of studied genes}

The relative mRNA expression of GHR1A, INSR, IGF1 and IGFBP2 mRNA in liver tissue is illustrated in Figure 2. Dietary supplementation of linseed (omega-3) for 2 months increased the relative mRNA abundance of INSR and GHR1A compared with the control and omega- 6 treatments $(\mathrm{P}<0.05)$. The mRNA abundance of INSR and total GHR1A were not different between the control and omega- 6 groups $(\mathrm{P}=0.202)$. There were no differences in IGFBP 2 mRNA levels among dietary treatments. 

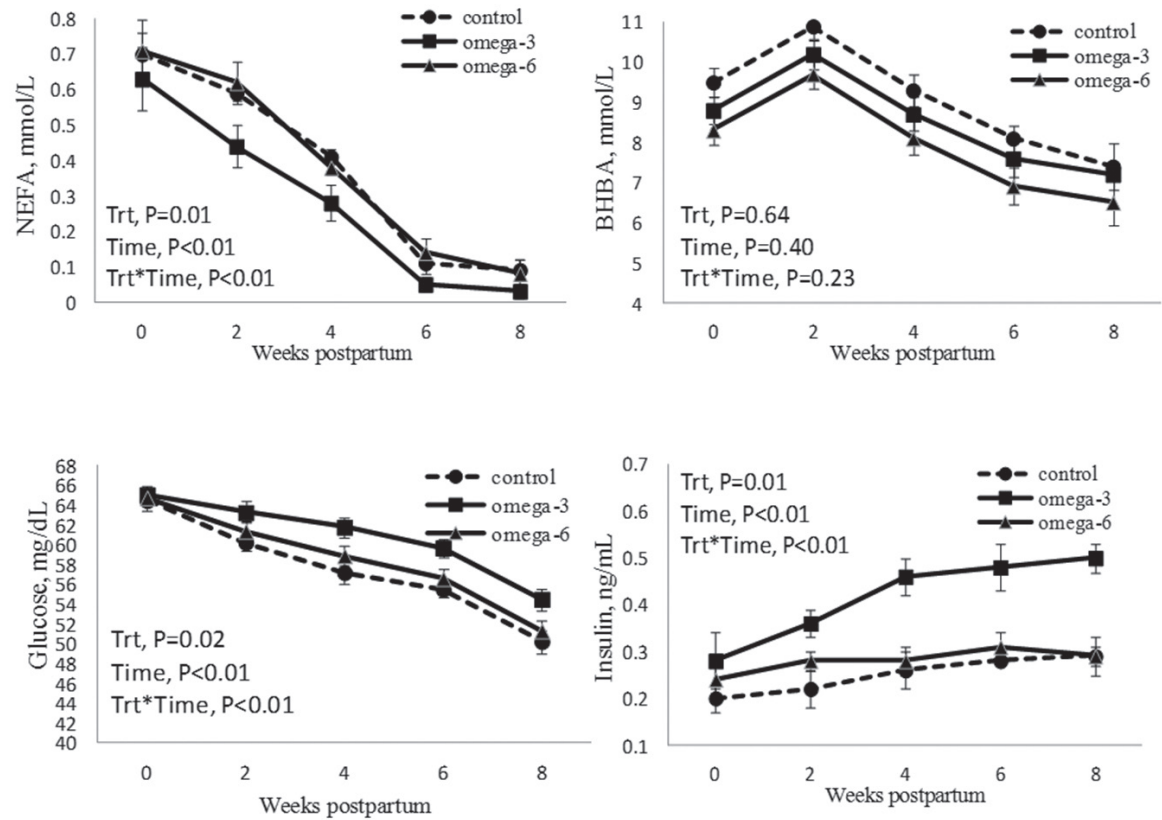

Figure 1. Mean ( \pm SEM) plasma NEFA, BHBBA, glucose and insulin concentrations in Holstein cows fed diets supplemented with palm oil (Control, $n=15$ ), linseed as a source of omega-3 PUFA (Omega-3, $\mathrm{n}=15$ ) or roasted whole soybean as a source of omega- 6 PUFA (Omega-6, $\mathrm{n}=15)$. Plasma samples were collected at $14 \mathrm{~d}$ interval from week 0 (calving) to 8 weeks postpartum

Table 4. Concentrations of plasma glucose, insulin, NEFA and BHBA in Holstein cows fed diets supplemented with palm oil (Control, $n=15$ ), linseed as a source of omega-3 PUFA (Omega-3, $n=15$ ) or roasted whole soybean as a source of omega-6 PUFA (Omega- $6, \mathrm{n}=15$ )

\begin{tabular}{l|c|c|c|c|c}
\hline \multirow{2}{*}{ Measurement } & \multicolumn{3}{|c|}{ Treatments } & \multirow{2}{*}{ S.E.M } & \multirow{2}{*}{ P } \\
\cline { 2 - 5 } & control & Omega-3 & Omega-6 & & \\
\hline IGF-I (ng/ml) & $100.2 \mathrm{a}$ & $120.1 \mathrm{~b}$ & $108.7 \mathrm{a}$ & 1.3 & 0.03 \\
Glucose (mg/dL) & $57.53 \mathrm{~b}$ & $60.87 \mathrm{a}$ & $58.59 \mathrm{~b}$ & 0.56 & 0.02 \\
Insulin (ng/ml) & $0.25 \mathrm{a}$ & $0.42 \mathrm{~b}$ & $0.28 \mathrm{a}$ & 0.01 & 0.01 \\
NEFA (nmol/mL) & $389 \mathrm{a}$ & $291 \mathrm{~b}$ & $325 \mathrm{~b}$ & 0.9 & 0.02 \\
BHBA (mg/dL) & 9.4 & 8.5 & 7.9 & 0.5 & 0.64 \\
\hline
\end{tabular}

a, $\mathrm{b}$ - means within a row with different superscripts differ $(\mathrm{P}<0.05)$. 

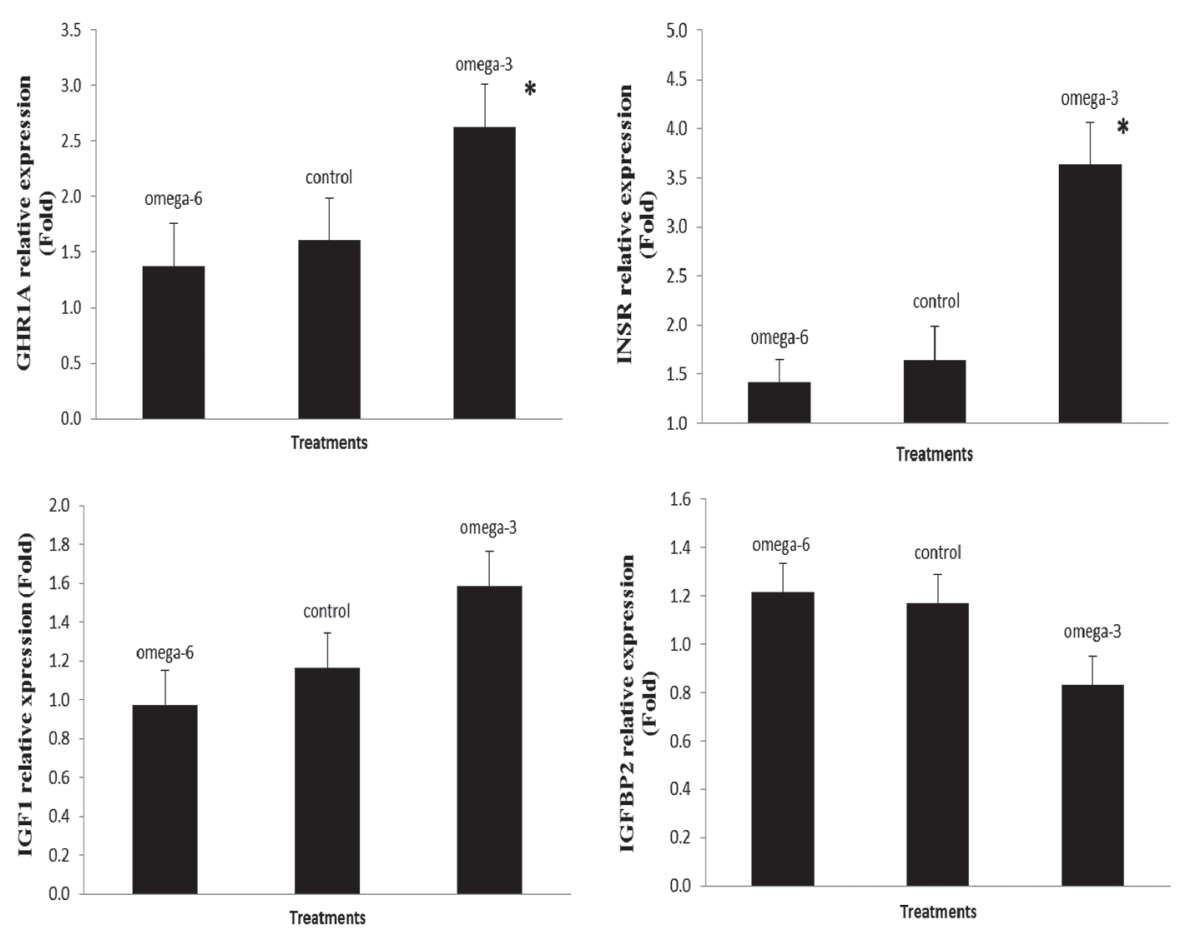

Significances are indicated in relation to the control group.

$*=\mathrm{P}<0.05$.

Figure 2. Relative expression levels for INSR, GHR1A, IGF-I and IGFBP2 mRNA on day $70 \mathrm{pp}$ in Holstein cows fed diets supplemented with omega-3, omega- 6 or saturated fatty acid (SFA; Control)

\section{Discussion}

The major finding of this study was that omega-3-fed cows had or tended to have higher expression of IGF1 and total GHR1A mRNAs in the liver than cows in the other two dietary treatments. In addition, cows fed a diet high in omega-3 had higher hepatic levels of INSR mRNA expression compared to control and roasted whole soybean (omega-6) fed cows. The plasma concentrations of IGF1 and insulin were also greater in cows fed omega-3 diets compared to those in the other two dietary groups.

Dietary treatments decreased NEFA concentrations that were consistent with previous studies (Badiei et al., 2014; Jahani et al., 2015). Blood concentration of NEFA is an index for body fat mobilization (Roberts et al., 1981) that is related to the energy balance of dairy cows. Bertics et al. (1992) reported that DM intake is inversely associated to concentrations of NEFA and BHBA in plasma and liver. 
Dietary fatty acid profile can modulate the whole-body response to insulin. Specifically, long-chain omega-3 PUFA (derived from fish oil) may prevent development of insulin resistance in humans and rodents (Delarue et al., 2004). In agreement with these findings, abomasal infusion of fish oil enhanced insulin-induced utilization of amino acid and glucose in the bovine, and increased key intermediaries in the intracellular insulin signaling cascade in muscle (Gingras et al., 2007). Glucose-stimulated insulin secretion can be affected directly by fatty acids. For example, palm oil can induce insulin secretion (insulinogenic) compared with unsaturated fatty acids (Dobbins et al., 2002). Both in vivo and in vitro studies demonstrated these effects; for instance feeding rats with different fat sources and by perfuming rat pancreas with distinct FA, respectively (Jucker et al., 1999).

An interesting finding, in the present study, was the upregulation of the mRNA abundance of GHR1A in the liver of cows fed diets supplemented with omega-3, which is thought to be a key change during the disrupting of the somatotropic axis in early lactation (McCarthy et al., 2009). As a consequence of coupling somatotropic axis, we also detected increased plasma IGF1 concentration of cows fed omega-3 FA, which was consistent with results from Gross et al. (2011). These changes reflect the expected differences of hepatic IGF1 synthesis (Butler et al., 2003). In cows, down-regulation of total GHR1A gene expression after parturition causes them to become refractory to $\mathrm{GH}$ at this time (Butler et al., 2003). In addition, GH attenuates the lipogenic response to insulin and simultaneously amplifies the lipolytic response to $\beta$-adrenergic signals (Bauman and Vernon, 1993). The loss of the GHR1A is responsible for the decreased IGF1 in postpartum cows (Radcliff et al., 2003). Therefore, greater total GHR1A would lead to more IGF1 synthesis and secretion (Radcliff et al., 2004; Rhoads et al., 2004, 2007). Total GHR1A mRNA expression was significantly increased in cows fed a diet supplemented with omega-3, which resulted in greater plasma IGF1concentrations in these cows compared to those in the control and omega- 6 dietary treatments. The decrease in medium-chain fatty acids and increase in long chain fatty acids concentrations of milk in cows fed omega- 3 and omega- 6 fatty acids were in general agreement with several previous studies in which cows were fed diets enriched with different PUFAs (Petit et al., 2004; Dirandeh et al., 2013 a, b). In bovine mammary tissue, acetyl CoA carboxylase regulates medium- and short-chain FA synthesis (Wright et al., 2006; Bionaz and Loor, 2008), suggesting that insulin may stimulate short-chain FA synthesis in this study.

Results from the present study showed that cows fed diets supplemented with omega-3 had the lowest plasma NEFA concentrations. The major effects of insulin on adipose tissue are to reduce lipolysis and to increase lipogenesis. Accordingly, if adipose tissue is resistant to insulin, the net effect will be mobilization of body reserves and increase in plasma NEFA concentrations. This is a normal response that occurs in early lactation in high producing dairy cattle. However, it is beneficial to avoid extreme loss of body condition score in early lactation.

In conclusion, supplementation of linseed altered hepatic expression of genes related to somatotropic axis function and concentrations of insulin, glucose and IGF1 in blood. Therefore, feeding diets supplemented with omega-3 FA during early 
postpartum couples with the somatotropic axis to increase plasma IGF1 concentration.

\section{Acknowledgements}

This research was supported by funds from University of Tehran, Iran National Science Foundation (INSF) and Sari Agricultural Science and Natural Resources University. The authors are grateful to Dr. Jean François Le Roux, R and D manager, Nutri Advance Feed and Ingredients, Parc technologique du Zoopole for the kind cooperation. We also thank the managers and staff of the Mahdasht dairy farm in the north part of Iran (Mazandaran province) for their assistance. The authors thank Prof. Marcos Colazo (Livestock Research Branch, Livestock Research and Extension Division, Alberta Agriculture and Forestry, Edmonton, Alberta, Canada) for critical review of the manuscript.

\section{References}

B adiei A., Aliverdilou A., A manlou H., B eheshti M., Dirandeh E., Masoumi R., Moos akhani F., Petit H.V. (2014). Postpartum responses of dairy cows supplemented with $n$-3 fatty acids for different durations during the peripartal period. J. Dairy Sci., 97: 6391-6399.

B a u m a n D.E., Ve rn on R.G. (1993). Effects of exogenous bovine somatotropin on lactation. Annu. Rev. Nutr., 13: 437-461.

B ell A.W., B a u m a n D.E. (1997). Adaptations of glucose metabolism during pregnancy and lactation. J. Mammary Gland. Biol. Neoplasia, 2: 265-278.

Bertics S.J., Grummer R.R., Cadorniga-Valino C., S toddard E.E. (1992). Effect of prepartum dry matter intake on liver triglyceride concentration and early lactation. J. Dairy Sci., 75: 1914-1922.

B i o n a z M., L o or J.J. (2008). Gene networks driving bovine milk fat synthesis during the lactation cycle. BMC Genomics, 9: 366.

B utle r S.T., M ar r A.L., P elt on S.H., R a d c 1 iff R.P., L u c y M.C., B ut l e r W.R. (2003). Insulin restores GH responsiveness during lactation-induced negative energy balance in dairy cattle: Effects on expression of IGF1 and GH receptor 1A. J. Endocrinology., 176: 205-217.

Clark e S.D. (2000). Polyunsaturated fatty acid regulation of gene transcription: a mechanism to improve energy balance and insulin resistance. Brit. J. Nutr., 83, Suppl. 1: S59-66.

De lar u e J., L e F o 11 C., C or pore a u C., L u c as D. (2004). Omega-3 long chain polyunsaturated fatty acids: a nutritional tool to prevent insulin resistance associated to type 2 diabetes and obesity? Reprod. Nutr. Develop., 4: 289-299.

Dirandeh D., Towhidi A., Ansari Pirsaraei Z., Adib Hashemi F., Ganjkhanlou M., Zeinoaldini S., Rezaei Roodbari A., Saberifar T., Petit H.V. (2013 a). Plasma concentrations of PGFM and uterine and ovarian responses in early lactation dairy cows fed omega-3 and omega-6 fatty acids. Theriogenology, 80: 131-137.

Dirandeh E., Towhidi A., Zeinoaldini S., Ganjkhanlou M., Ansari Pirsaraei Z., F o u l a d i - N a sht a A., (2013 b). Effects of different polyunsaturated fatty acid supplementations during the postpartum periods of early lactating dairy cows on milk yield, metabolic responses, and reproductive performances. J. Animal Sci., 91: 713-721.

Dirandeh E., Towhidi A., Ansari Pirsaraei Z., Saberifar T., Akhlaghi A., Re$\mathrm{z}$ a e i R o od b ari A. (2015). The endometrial expression of prostaglandin cascade components in lactating dairy cows fed different polyunsaturated fatty acids. Theriogenology, 83: 206-212.

Dobbins R.L., Szczepaniak L.S., Myhill J., Tamura Y., Uchino H., Giacca A. (2002). The composition of dietary fat directly influences glucose-stimulated insulin secretion in rats. Diabetes, 51: 1825-1833. 
Edmons on A.J., Le an I.J., We a ver L.D., F a rver T., We b st e r G. (1989). A body condition scoring chart for Holstein dairy cows. J. Dairy Sci., 72: 68-78.

F enwick M.A., Fitzpatrick R., Kenny D.A., Diskin M.G., Patton J., Murphy J.J., W a the s D.C. (2008). Interrelationships between negative energy balance (NEB) and IGF regulation in liver of lactating dairy cows. Domest. Anim. Endocrinol., 34: 31-44.

F olch J., Lees M., S lo an e S tanley G.H. (1957). A simple method for the isolation and purification of total lipids from animal tissues. J. Biol. Chem., 226: 497-509.

Gingras A.A., White P.J., Chou inard P.Y., Julien P., Davis T.A., Dombrowski L. (2007). Long-chain omega-3 fatty acids regulate bovine whole-body protein metabolism by promoting muscle insulin signaling to the akt-mtor-s6k1 pathway and insulin sensitivity. J. Physiol., 579: $269-284$.

Gros s J., van D or land H.A., S chwarz F.J., B ruck ma i e r R.M. (2011). Endocrine changes and liver mRNA abundance of somatotropic axis and insulin system constituents during negative energy balance at different stages of lactation in dairy cows. J. Dairy Sci., 93: 3484-3494.

Jahani-Moghadam M., Mahjoobi E., Dirandeh E. (2015). Effect of linseed feeding on blood metabolites, incidence of cystic follicles and productive and reproductive performances in fresh Holstein dairy cows. J. Dairy Sci., 98: 1828-1835.

J u c k e r B.M., C 1 in e G.W., B a r u c c i N., S h u $1 \mathrm{~m}$ a n G.I. (1999). Differential effects of safflower oil versus fish oil feeding on insulin-stimulated glycogen synthesis, glycolysis, and pyruvate dehydrogenase flux in skeletal muscle. Diabetes, 48: 134-140.

L e o n a r d M., B l o c k E. (1997). Effects of nutrition and hormonal profile of long-term infusions of glucose or insulin plus glucose in cows treated with recombinant bovine somatotropin before peak milk yield. J. Dairy Sci., 80: 127-143.

L e o n a rd J.L., Vis s er T.J., L e o n a rd D.B. (2001). Characterization of the subunit structure of catalytically active type I iodothyronine deiodinase. J. Biol Chem., 276: 2600-2607.

L u c y M.C. (2008). Functional differences in the growth hormone and insulin-like growth factor axis in cattle and pigs: Implications for post-partum nutrition and reproduction. Reprod. Dom. Anim., 43: 31-39.

McCarthy S.D., Butler S.T., Patton J., Daly M., Morris D.G., Kenny D.A., Waters S.M. (2009). Differences in the expression of genes involved in the somatotropic axis in divergent strains of Holstein-Friesian dairy cows during early and mid lactation. J. Dairy Sci., 92: 5229-5238.

NRC (2001). Nutrient Requirements of Dairy Cattle. 7th ed. National Academy of Science, Washington, DC.

O a kes N.D., C o on ey G.J., C a mille ri S., Ch is holm D.J., Kra e ge n E.W. (1997). Mechanisms of liver and muscle insulin resistance induced by chronic high-fat feeding. Diabetes, 46: $1768-1774$.

P a t t o n J., K e n n y D.A., M c N a m a r a S., M e e J.F., M a r a F.P.O., D is k in M.G., M u r p h y J.J. (2007). Relationships among milk production, energy balance, plasma analytes, and reproduction in Holstein-Friesian cows. J. Dairy Sci., 90: 649-658.

P et it H.V., Germiquet C., Le bel D. (2004) Effect of feeding whole, unprocessed sunflower seeds and flaxseed on milk production, milk composition, and prostaglandin secretion in dairy cows. J. Dairy Sci., 87: 3889-3898.

P ires J.A., S ouza A.H., Grummer R.R. (2007). Induction of hyperlipidemia by intravenous infusion of tallow emulsion causes insulin resistance in Holstein cows. J. Dairy Sci., 90: 2735-2744.

R a d c 1 iff R.P., M c C or m a c k B.L., C r o o k e r B.A., L u c y M.C. (2003). Plasma hormones and expression of growth hormone receptor and insulin-like growth factor-I mRNA in hepatic tissue of periparturient dairy cows. J. Dairy Sci., 8: 3920-3926.

Radcliff R.P., Vande Haar M.J., Kobayashi Y., Sharma B.K., Tucker H.A., Lu c y M.C., (2004). Effect of dietary energy and somatotropin on components of the somatotropic axis in Holstein heifers. J. Dairy Sci., 87: 1229-1235.

Renaville R., Hammadi M., Portetelle D. (2002). Role of somatotropic axis in the mammalian metabolism. Domest. Anim. Endocrinol., 23: 351-360.

Rhoads R.P., Kim J.W., L eury B.J., B aumgard L.H., S e go a le N., Frank S.J., B au- 
$\mathrm{m}$ a n D.E., B o i s c l a ir Y.R. (2004). Insulin increases the abundance of the growth hormone receptor in liver and adipose tissue of periparturient dairy cows. J. Nutr., 134: 1020-1027.

Rho a d s R.P., K i m J.W., Van A m burgh M.E., Ehrhard t R.A., Frank S.J., B o is c la ir Y.R. (2007). Effect of nutrition on the GH responsiveness of liver and adipose tissue in dairy cows. J. Endocrinol., 195: 49-58.

R h o a d s M.L., M e y e r J.P., L a m b e r s o n W.R., K e is 1 e r D.H., L u c y M.C. (2008). Uterine and hepatic gene expression in relation to days postpartum, estrus, and pregnancy in postpartum dairy cows. J. Dairy Sci., 91: 140-150.

Roberts C.J., Reid I.M., Rowlands G.J., Patterson A. (1981). A fat mobilisation syndrome in dairy cows in early lactation. Vet. Rec., 108: 7-9.

W a the s D.C., T a y lor V.J., Ch e ng Z., M a n n G.E. (2003). Follicle growth, corpus luteum function and their effects on embryo development in postpartum dairy cows. Reproduction, Suppl., 61: 219-237.

Wright T.C., Cant J.P., B renna J.T., Mc Bride B.W. (2006). Acetyl CoA carboxylase shares control of fatty acid synthesis with fatty acid synthase in bovine mammary homogenate. J. Dairy Sci., 89: 2552-2558.

Received: 14 XII 2015

Accepted: 21 III 2016 